\title{
Break-up of monopoly?
}

\section{Tokyo}

JAPAN's domestic telecommunications giant, Nippon Telegraph and Telephone (NTT), may be broken up into regional companies if recommendations in an interim report released last week by the Telecommunications Council, an advisory body to the Ministry of Posts and Telecommunications, are followed. But resistance to break-up is strong and it is not clear what path the government will take when the council's final recommendations are issued next March.

With 270,000 employees and an operating income of about $\$ 45,000$ million, NTT is one of the largest companies in the world. Although it was privatized in 1985, and three competitors entered the market, NTT still controls about 98 per cent of the market, and long-distance domestic telecommunications charges remain high. Japan's international telecommunications charges, in contrast, are tumbling as a result of competition (see below).

Of a number of ways to break up the NTT monopoly, the council favours a split into one long-distance company and 11 regional companies, similar to the breakup of the US monopoly American Telephone and Telegraph (AT\&T).

The council argues that the split will

\section{Time to call Japan}

\section{Tokyo}

A PRICE war may be about to begin in Japan's international telecommunications market, only recently opened up to competition. On 1 October, two new telecommunications companies, International Telecom Japan (ITJ) and International Digital Communications (IDC), began international telephone services with rates 23 to $\mathbf{4 0}$ per cent lower than those of the former monopoly Kokusai Denshin Denwa (KDD). But just before the services began, KDD announced new rates, effective from 1 November, that are almost as cheap as those of the new companies. KDD had already reduced its rates considerably in anticipation of competition.

The new companies were at the centre of a trade dispute with the United Kingdom and the United States two years ago, when the Japanese government tried to block participation of Britain's Cable and Wireless and other foreign companies in IDC. One concern of the government has been that establishment of the new companies could result in "excessive competition". Both companies have said they will offer rates considerably cheaper than those of KDD, and a spokesman for IDC says further price reductions are under consideration.

David Swinbanks promote competition, reduce rates for users, and turn NTT into a more productive entity. But both the powerful Japan Telecommunications Workers Union, to which NTT employees belong, and NTT president Haruo Yamaguchi have come out publicly against the council's recommendations. Yamaguchi says that breakup would increase local rates and create regional differences in charges, and adds that it would interfere with NTT's development of a digital Information Network System (INS) and weaken NTT's research and development capabilities. But opinions in NTT management are said to be divided, with those on the sales and administrative side favouring restructuring while those with an engineering background tend to oppose it.

Proposals to split up NTT when it was

\section{HYDROELECTRICITY Indian dams go ahead} Bangalore

To the disappointment of Indian environmentalists, the World Bank has not only agreed to provide around 10 per cent of the estimated cost of the gigantic Narmada Sagar-Sardar Sarovar dam project but has also expressed its satisfaction over the plans drawn up to resettle the people evacuated to make room for it. The US Environmental Defense Fund and Environmental Policy Institute had earlier appealed to the World bank to withdraw its support, but the bank has apparently been impressed by the work of Sanat Mehta, chairman of the Sardar-Sarovar Narmada Sagar Nigam, an agency charged with the task of speeding up the project and dealing with the evacuees.

In its present form, the Narmada Sagar and Sardor-Sarovar project together are designed to yield about 2,500 MW of hydroelectric power and will irrigate about 2 million hectares. The entire scheme involves the construction of 30 major dams, and many smaller ones, on the Narmada river and its tributaries. Mehta says that those affected will be given irrigable land, housing plots, agricultural aid, resettlement grants, free transport and civic amenities. This offer is, he says, "unparalleled and unmatched in the world". But a recent study commissioned by the Indian National Trust for Art and Cultural Heritage (INTACH) concludes that the objectives set out by the planners will not be achieved with the present plans. V. Paranjype of INTACH fears that the whole project will come to a halt within two or three years for lack of funds, and that money intended for rehabilitation will go elsewhere.

Radhakrishna Rao privatized in 1985 were shelved because of strong opposition from NTT and some members of the ruling Liberal Democratic Party. Now, however, NTT has lost a lot of political influence because of its involvement in the Recruit scandal which forced the resignation of the then Prime Minister. But NTT still has many powerful friends, including the Federation of Economic Organizations (Keidanren) which opposes break-up.

An important element in the government's thinking will be the effect of breakup on the price of NTT shares. The government has been selling off NTT shares to the public and using the proceeds to help pay off the national debt and finance public works construction. But after rising to a high of about $\mathbf{Y} 3$ million (about $\$ 20,000$ ) per share the price has plummeted to $¥ 1.4$ million and the next sale of government-held shares has been postponed.

David Swinbanks

\section{AIDS TREATMENT 'Parallel trick' for ddl}

\section{Washington}

THE announcement that dideoxyinosin (ddI) will be made available to AIDS patients outside the current clinical trials is a victory for AIDS activists, who have been fighting for early access to drugs working their way through the drug-approval process of the US Federal Drug Administration (FDA). But the victory is tempered by signs that the drug may be more toxic than originally reported.

Results from the recently completed 'Phase 1' safety trials show that ddI, a nucleoside analogue that blocks HIV (human immunodeficiency virus) replication, may be toxic at higher doses, causing nerve damage to the feet and damage to the pancreas. Researchers at the National Institute of Allergy and Infectious Diseases are now ready to begin 'Phase 2' trials, in which the drug's efficacy will be compared to that of AZT, still the only AIDS drug approved for widespread use. Fewer than 30 patients took part in the phase 1 trials, but more than 2,500 will take part in phase 2 . At the same time, ddI will be made available to patients who cannot tolerate AZT, or for whom AZT has been ineffective, through a programme administered and funded by Bristol-Myers, the manufacturer of ddI.

With this announcement, the FDA took the first steps towards the much-publicized 'parallel track' mechanism for simultaneous drug testing and distribution. But it remains to be seen whether widespread distribution of ddI will reduce participation in the clinical trials, and there is doubt too over the ethics of approving a drug about which information is still scarce and which may cause serious toxic side-effects.

Christine McGourty 